\title{
ANALISIS YURIDIS TINDAKAN DISKRESI KEPOLISIAN PADA TAHAP PENYIDIKAN
}

\author{
Sahata Manalu \\ Fakultas Hukum Universitas Katolik Santo Thomas, Medan, Indonesia \\ Email :manalusahata75@gmail.com
}

\begin{abstract}
ABSTRAK
Dalam melaksanakan tugas profesinya, Polri memiliki kewenangan diskresi yang dapat dilaksanakan dalam keadaan tertentu. Diskresi adalah sebuah wewenang yang diberikan hukum kepada aparat penegak hukum, khususnya kepolisian untuk bertindak dalam situasi khusus sesuai dengan penilaian dan kata hati instansi atau petugas sendiri. Rumusan penelitian ini adalah: 1). Bagaimana Pelaksanaan diskresi kepolisian pada tahap penyidikan; dan 2). Sejauhmana Efektifitas Pelaksanaan diskresi kepolisian pada tahap penyidikan. Penelitian ini merupakan penelitian hukum normatif, yaitu menggunakan bahan hukum sekunder sebagai data utama. Dari hasil penelitian ini disimpulkan bahwa 1) Penggunaan diskresi kepolisian dalam penghentian penyidikan, tampak adanya wewenang dalam hal atau keadaan tertentu untuk mengambil keputusan apakah akan dilakukan tindakan atau tidak apabila terjadi suatu tindak pidana dan terdapat faktor-faktor yang mempengaruhi diskresi kepolisian dalam penghentian penyidikan antara lain faktor undangundang; faktor penegak hukum; faktor masyarakat; faktor sarana prasarana; dan faktor budaya hukum; 2. Pelaksanaan diskresi secara efektif harus dilakukan dengan penuh kehati-hatian dengan meningkatkan kualitas sumberdaya manusia dibidang penegakan hukum serta kekuasaan atau wewenang yang dilakukan berdasarkan hukum atas dasar pertimbangan dan keyakinan dan lebih menekankan pada pertimbangan moral ketimbang pertimbangan hukum serta memberikan keadilan yang nyata dengan memperhatikan sisi resiko dan kemanfaatan dari suatu tindakan yang dilaksanakan
\end{abstract}

\section{Kata Kunci: Analisis Yuridis, Diskresi Kepolisian, Penyidikan}

\section{ABSTRACT}

In carrying out its professional duties, the National Police has the authority of discretion that can be carried out in certain circumstances. Discretion is an authority given by law to law enforcement officers, especially the police to act in special situations in accordance with the judgment and conscience of the agency or the officer himself. This research formula is: 1). How to implement police discretion at the investigation stage; and 2). How far the effectiveness of the implementation of police discretion at the investigation stage. This research is a normative legal research, which uses secondary legal material as the main data. From the results of this study concluded that 1) The use of police discretion in stopping investigations, it appears that there is authority in certain cases or circumstances to make a decision whether to take action or not if a crime occurs and there are factors that influence the discretion of the police in stopping investigations between Other legal factors; law enforcement factors; community factors; infrastructure factors; and legal cultural factors; 2. The effective implementation of discretion must be carried out with caution by improving the quality of human resources in 
the field of law enforcement as well as the power or authority that is carried out based on law based on considerations and beliefs and emphasizes more on moral considerations rather than legal considerations and provides real justice by paying attention the risk and benefit side of an action taken

Keywords: Juridical Analysis, Police Discretion, Investigation

\section{A. PENDAHULUAN}

Dalam melaksanakan tugas profesinya, Polri memiliki kewenangan diskresi yang dapat dilaksanakan dalam keadaan tertentu. Diskresi dapat dilakukan oleh aparat kepolisian dalam praktik dalam hal bertujuan untuk mengutamakan pencapaian tujuan sasaran daripada keberlakuan hukum yang ada. Untuk dapat dilaksanakannya diskresi, harus terpenuhi tiga syarat yakni demi kepentingan umum, masih dalam lingkup kewenangannya dan tidak melanggar asas-asas umum pemerintahan yang baik.

Diskresi adalah sebuah wewenang yang diberikan hukum kepada aparat penegak hukum, khususnya kepolisian untuk bertindak dalam situasi khusus sesuai dengan penilaian dan kata hati instansi atau petugas sendiri. Diskresi sesungguhnya merupakan kelengkapan dari sistem pengaturan oleh hukum itu sendiri. Dengan kewenangan seperti itu, seharusnya aparat kepolisian lebih jeli dalam penerapan hukum kepada masyarakat dengan melihat substansi perkara yang akan dilanjutkan proses penanganannya sehingga tidak melukai rasa keadilan masyarakat.

Hal inilah yang kemudian harus dikaji, apakah pemberian kewenangan diskresi yang telah diberikan Undang-undang kepada pihak kepolisian untuk memilah-milah perkara yang akan diproses lebih lanjut telah dapat digunakan dengan baik oleh pihak kepolisian sehingga dapat mencerminkan rasa keadilan dan profesionalisme Polri.

Diskresi diperlukan karena lingkup aturan tidak menjangkau secara komprehensif dan detail bagaimana setiap Pejabat dapat menjalankan tugas, wewenang dan tanggungjawabnya di lapangan, sehingga diperlukan ada pertimbangan dan kebijakan subyektif dari Pejabat publik bersangkutan demi kelancaran tugas-tugasnya.

Dasar hukum penggunaan diskresi diatur dalam UU Polri Nomor 2 tahun 2002 tentang Kepolisian dan Undang-undang Nomor 8 tahun 1981 tentang Hukum 
Acara Pidana (KUHAP). Dalam pasal 15 ayat (2) huruf k jo. Pasal 16 ayat (1) huruf 1 UU Polri Nomor 2 tahun 2002 disebutkan:

Dalam rangka menyelenggarakan tugas di bidang proses pidana, Polri berwenang untuk mengadakan tindakan lain dalam bentuk tindakan penyelidikan dan penyidikan yang dilaksanakan sebagai berikut:

a) tidak bertentangan dengan suatu aturan hukum;

b) selaras dengan kewajiban hukum yang mengharuskan tindakan tersebut dilakukan;

c) harus patut, masuk akal, dan termasuk dalam lingkungan jabatannya;

d) pertimbangan yang layak berdasarkan keadaan yang memaksa; dan

e) menghormati hak asasi manusia.

Pada beberapa peristiwa dalam praktik, tindakan untuk mengesampingkan perkara dalam rangka menahan atau tidak melakukan penahanan terhadap tersangka/pelaku pelanggaran hukum atau menghentikan proses penyidikan, atau melakukan tindakan seketika bukanlah tindakan diskresi individual petugas Kepolisian. Tindakan tersebut merupakan tindakan diskresi birokrasi karena dalam pengambilan keputusan diskresi berdasarkan atau berpedoman pada kebijaksanaankebijaksanaan pimpinan dalam organisasi dan hal tersebut telah dijadikan kesepakatan diantara mereka. Pada beberapa kasus penggunaan diskresi kepolisian dilakukan dalam bentuk penyelesaian perkara secara kekeluargaan, meskipun pada dasarnya aturan tertulis yang mengatur tentang peristiwa tersebut sudah sangat jelas tertulis dalam ketentuan undang-undang.

Berkaitan dengan pelaksanaan tugas dan wewenang Polri, dalam Pasal 18 UU Polri Nomor 2 Tahun 2002 mengatur kewenangan mengenai "Diskresi Kepolisian", dimana Polri memiliki wewenang untuk bertindak menurut penilaiannya sendiri dalam rangka kewajiban umumnya guna menjaga, memelihara, ketertiban dan menjamin keamanan umum, dan keabsahannya didasarkan pada pertimbangan keperluannya untuk pelaksanaan tugas dan kewajiban. Namun yang perlu ditekankan di sini adalah bahwa penggunaan diskresi dalam pelaksanaan tugas kepolisian merupakan wewenang yang diberikan negara sebagai salah satu perwujudan pencapaian tujuan. Penggolongan diskresi dalam kategori "kewenangan" mengindikasikan bahwa penggunaannya, diskresi tidak 
dapat diterapkan secara serta merta, melainkan harus dilaksanakan sesuai dengan standar operasional prosedur serta memenuhi persyaratan tertentu.

Pelaksanaan kewenangan sangat berbeda dengan peristilahan penggunaan "hak" dalam hukum. Penggunaan hak, cenderung bersifat bebas dan tidak bergantung pada keadaan apapun, dalam artian bahwa selama hak itu digunakan oleh si pemegang hak, maka penggunaan hak tidak dapat diganggu gugat. Berbeda dengan peristilahan "kewenangan" dimana penggunaanya tidak bersifat serta merta, dalam artian bahwa penggunaan kewenangan terikat pada suatu aturan yang mengatur tentang syarat penggunaan kewenangan.

Dalam konteks penggunaan kewenangan diskresi, aparatur kepolisian diikat oleh serangkaian aturan yang memposisikannya sebagai pihak yang berwenang, sehingga dalam menggunakan kewenangan diskresi, aparatur kepolisian tidak boleh serta merta, melainkan harus tunduk pada peraturan-perundang-undangan yang berlaku serta standar prosedur operasional yang berlaku dalam instansi Kepolisian.

Berdasar pada latar belakang masalah di atas, maka timbul permasalahan sebagai berikut: 1) Bagaimana Pelaksanaan diskresi kepolisian pada tahap penyidikan?; dan 2) Sejauhmana Efektifitas Pelaksanaan diskresi kepolisian pada tahap penyidikan?

\section{B. METODE PENELITIAN}

Penelitian ini merupakan penelitian hukum normatif, yaitu menggunakan bahan hukum sekunder sebagai data utama. Penelitian hukum normatif ini adalah penelitian dibidang hukum yang bertujuan mencari kaedah hukum. Penelitian hukum normatif ini juga menggunakan bahan hukum primer seperti peraturan perundang-undangan. Pengumpulan data melalui penalaran kepustakaan dengan cara mempelajari, menganalisa, dan menelaah literatur-literatur, karya ilmiah, dokumen/arsip, dan tulisan yang berhubungan dengan penelitian ini.

\section{PEMBAHASAN}

\section{Pengertian Kepolisian Negara Republik Indonesia}

Moylan mengemukakan pendapatnya mengenai arti serta pengertian kepolisian sebagai berikut: ${ }^{1}$

${ }^{1}$ Moylan, 1953, Pengertian Kepolisian, Gramedia Widia Sarana Indonesia, Jakarta, hlm. 4. 
"Istilah polisi sepanjang sejarah ternyata mempunyai arti yang berbedabeda dalam arti yang diberikan pada semulanya. Juga istilah yang diberikan oleh tiap-tiap negara terhadap pengertian "polisi” adalah berbeda oleh karena masingmasing negara cenderung untuk memberikan istilah dalam bahasanya sendiri. Misalnya istilah "contable" di Inggris mengandung arti tertentu bagi pengertian "polisi", yaitu bahwa contable mengandung dua macam arti, pertama sebagai satuan untuk pangkat terendah di kalangan kepolisian (police contable) dan kedua berarti kantor polisi (office of constable)".

Di samping itu istilah "police" dalam Bahasa Inggris mengandung arti yang lain, seperti yang dinyatakan oleh Charles Reith mengutip dari buku Anton Tabah dalam bukunya ${ }^{2}$ "The Blind Eya of History" yang mengatakan "Police in the English language came to mean any kind of planing for improving of ordering communal existence". Dari definisi tersebut dapat diartikan bahwa Charles Reith mengatakan bahwa polisi dituntut mengayomi masyarakat namun di satu sisi polisi dapat melakukan tindakan hukum dari beratnya kejahatan.

Perkembangan selanjutnya di Indonesia dikenal istilah "Hukum Kepolisian" adalah istilah majemuk yang terdiri atas kata "Hukum" dan "Kepolisian". Jadi menurut arti tata bahasa istilah "Hukum Kepolisian" adalah hukum yang mengatur segala sesuatu yang bertalian dengan polisi.

Dalam Pasal 1 Bab I Ketentuan Umum Poin 1 Undang-Undang Nomor 2 Tahun 2002 tentang Kepolisian Negara Republik Indonesia bahwa "Kepolisian adalah segala hal-hal yang berkaitan dengan fungsi dan lembaga polisi sesuai dengan peraturan perundang-undangan"3.

Sedangkan menurut Pasal 5 ayat (1) pada undang-undang yang sama, Kepolisian Negara Republik Indonesia dikatakan alat negara yang berperan dalam memelihara keamanan dan ketertiban masyarakat, menegakkan hukum serta memberikan perlindungan, pengayoman, dan pelayanan kepada masyarakat dalam rangka terpeliharanya keamanan dalam negeri.

\section{Tugas dan Wewenang Kepolisian Negara Republik Indonesia}

\footnotetext{
${ }^{2}$ Anton Tabah, 2002, Membangun Polri yang Kuat (Belajar Macam-Macam Asia), Mitra Hardhasuma, Jakarta, hlm. 33.

${ }^{3}$ Undang-Undang Nomor 2 Tahun 2002 tentang Kepolisian Negara Republik Indonesia.
} 
Polri secara universal mempunyai tugas yang sama yaitu sebagai aparat yang bertugas menjaga keamanan dan ketertiban masyarakat serta aparat penegak hukum, walaupun dalam praktek di masing-masing negara mempunyai pola dan prosedur kerja yang berbeda. Dengan berkembangnya peradaban manusia dan berkembangnya pola kejahatan maka tugas Polisi semakin berat dan kompleks.

Fungsi Kepolisian Negara Republik Indonesia dapat dilihat dalam Undang-Undang Dasar Negara Republik Indonesia 1945 Pasal 30 ayat (4) (setelah diamandeman): " "Kepolisian Negara Republik Indonesia sebagai alat negara yang menjaga keamanan dan ketertiban masyarakat bertugas melindungi, mengayomi, melayani masyarakat serta menegakkan hukum”.

Berdasarkan pasal tersebut di atas sangat jelas bahwa prioritas pelaksanaan tugas Polri adalah pada penegakan hukum. Ini berarti tugas-tugas kepolisian lebih diarahkan kepada bagaimana cara menindak pelaku kejahatan sedangkan perlindungan dan pelayanan masyarakat merupakan prioritas kedua dari tindakan kepolisian.

Sebagai wujud dari peranan Polri, maka dalam mengambil setiap kebijakan harus didasarkan pada pedoman-pedoman yang ada. Dibawah ini penulis menguraikan pedoman-pedoman sebagaimana yang dimaksud:

\section{Penyidik Kepolisian}

Maksud dari penyidik menurut Undang-Undang Nomor 8 tahun 1981 tentang Kitab Undang-undang Hukum Acara Pidana pada Pasal 1 butir (1) adalah pejabat Polisi Negara Republik Indonesia atau Penyidik Pegawai Negeri Sipil tertentu yang diberi wewenang khusus oleh undang-undang untuk melakukan penyidikan. ${ }^{5}$ Dalam ketentuan umum UU Polri Nomor 2 tahun 2002 tentang Kepolisian Negara Republik Indonesia disebutkan bahwa penyidik adalah pejabat Kepolisian Negara Republik Indonesia yang diberi wewenang oleh Undang-undang untuk melakukan penyidikan, sedangkan yang berhak menjadi penyidik menurut Pasal 2A Ayat (1) Peraturan Pemerintah Republik Indonesia No. 58 Tahun 2010 tentang pelaksanaan KUHAP adalah: Pejabat

${ }^{4}$ Undang-Undang Dasar Negara Republik Indonesia 1945.

${ }^{5}$ Undang-Undang Nomor 8 tahun 1981 tentang Kitab Undang-Undang Hukum Pidana. 
Polisi Negara Republik Indonesia tertentu yang sekurang-kurangnya berpangkat Inspektur Dua Polisi dan berpendidikan paling rendah sarjana strata satu atau yang setara. ${ }^{6}$

Ketentuan diatas dengan pengecualian, jika disuatu tempat tidak ada pejabat penyidik sebagaimana dimaksud maka Kepala Kepolisian Negara Republik Indonesia atau Pejabat Kepolisian Negara Republik Indonesia yang ditunjuk karena jabatannya dapat menunjuk Inspektur Dua Polisi lain sebagai penyidik, hal tersebut sesuai dalam Pasal 2B Peraturan Pemerintah Republik Indonesia No. 58 Tahun 2010 Tentang Pelaksanaan KUHAP.

Penyidik dari Polri yang berwenang melakukan penyidikan saat ini minimal harus seorang Polisi dengan pangkat minimal Inspektur Dua Polisi (Ipda), sedangkan untuk seorang Polisi yang bertugas sebagai penyidik pembantu berasal dari Bintara Polisi dengan pangkat minimal Brigadir Polisi Dua (Bripda), Brigadir Polisi Satu (Briptu), Brigadir atau Brigadir Kepala (Bripka) dengan syarat lulus pendidikan pengembangan spesialisasi fungsi reserse criminal, bertugas dibidang penyidikan paling singkat 2 tahun, sehat jasmani dan rohani dengan dibuktikan surat keterangan Dokter serta memiliki kemampuan dan integritas moral yang tinggi.

Pada KUHAP dan UU Polri Nomor 2 tahun 2002, untuk meringankan beban penyidik juga telah diatur adanya penyidik pembantu. Penyidik pembantu adalah pejabat Kepolisian Negara Republik Indonesia yang diangkat oleh kepala Kepolisian Negara Republik Indonesia berdasarkan syarat kepangkatan yang diberi wewenang tertentu dalam melaksanakan tugas penyidikan yang diatur dalam undang-undang.

Pejabat Penyidik Pembantu dalam KUHAP diatur dalam Pasal 10, selanjutnya Pasal 3 Peraturan Pemerintah Nomor 58 Tahun 2010 Tentang Pelaksanaan KUHAP menentukan bahwa:

1) Penyidik pembantu adalah pejabat Kepolisian Negara Republik Indonesia yang memenuhi persyaratan sebagai berikut:

a. berpangkat paling rendah Brigadir Dua Polisi; KUHAP.

${ }^{6}$ Peraturan Pemerintah Republik Indonesia Nomor 58 Tahun 2010 tentang pelaksanaan 
b. mengikuti dan lulus pendidikan pengembangan spesialisasi fungsi reserse kriminal;

c. bertugas dibidang fungsi penyidikan paling singkat 2 (dua) tahun;

d. sehat jasmani dan rohani yang dibuktikan dengan surat keterangan dokter; dan

e. memiliki kemampuan dan integritas moral yang tinggi.

2) Penyidik pembantu sebagaimana dimaksud pada ayat (1) diangkat oleh Kepala Kepolisian Negara Republik Indonesia atas usul komandan atau pimpinan kesatuan masing-masing.

3) Wewenang pengangkatan sebagaimana dimaksud pada ayat (2) dapat dilimpahkan kepada pejabat Kepolisian Negara Republik Indonesia yang ditunjuk oleh Kepala Kepolisian Negara Republik Indonesia;

Wewenang Penyidik Pembantu ini hampir sama dengan penyidik pada umumnya, kecuali pada kewenangan penahanan. Dalam hal penahanan, penyidik pembantu harus menunggu terlebih dahulu pelimpahan wewenang dari penyidik. Dalam pembuatan berita acara dan berkas perkara yang tidak langsung diserahkan kepada penuntut umum, tetapi diserahkan kepada penyidik, kecuali dalam perkara dengan pemeriksaan singkat.

Dalam melakukan pemeriksaan, seorang penyidik harus taat pada standard operasional prosedur (SOP) disamping KUHAP, Peraturan Pemerintah, ataupun Perkab. Dalam Perkaba SOP tentang Pelaksanaan Penyidikan Tahun 2012 terdapat beberapa prinsip dan azas yang menjadikan pedoman atau petunjuk dalam melaksanakan pemeriksaan atau penyidikan, prinsip dan azas tersebut dijelaskan dalam Pasal 3 Perkaba SOP Pelaksanaan Penyidikan Tahun 2012, prinsip dan azas dalam peraturan tersebut adalah:

(1)Akuntabel: mengutamakan akuntabilitas dalam penyidikan dengan melibatkan pemangku kepentingan dan dapat dipertanggungjawabkan;

(2)Professional: meningkatkan kapasitas dan kemampuan penyidik sehingga dapat memberikan pelayanan yang mudah, cepat dan proporsional;

(3)Responsif: meningkatkan kepekaan penyidik dalam menindaklanjuti laporan masyarakat. 
(4)Transparan: proses dan hasil penyidikan di laksanakan secara terbuka dan dapat di monitor dengan mudah oleh pihak yang berkepentingan sehingga masyarakat dapat mengakses informasi seluas-luasnya dan akurat;

(5)efisien dan efektif: pelaksanaan penyidikan berjalan dengan baik dan mencapai sasaran yang di harapkan;

(6)Dalam melaksanakan proses penyidikan, penyidik memperhatikan:
a. hak tersangka sesuai KUHAP;
b. hak pelapor dan pengadu;
c. hak saksi korban;
d. hak asasi manusia;
e. azas persamaan dimuka hukum;
f. azas praduga tak bersalah;
g. azas legalitas;
h. azas kepatutan, kecuali dalam hal diatur dalam undang - undang lain;
i. memperhatikan etika profesi Kepolisian

Pasal dalam SOP tersebut mendeskripsikan kewajiban seorang penyidik dalam melaksankan tugas dan kewajibannya sebagai penyidik dengan melihat azas penugasan serta mengedepankan hak dari seseorang yang dijadikan subyek dari pemeriksaan penyidikan untuk mencegah kesewenang-wenangan dalam penyidikan. Disamping itu dalam menjalankan tugas perpolisiannya, seorang Polisi selaku aparat penegak hukum dapat bekerja lebih maksimal dan professional dalam melaksanakan pemeriksaan juga diatur dalam Perkaba SOP tersebut, yakni:

1) Dalam melaksanakan pemeriksaan, penyidik memperhatikan norma hukum, antara lain:
a. etis, humanis, dan memegang prinsip etika profesi penyidikan;
b. hak dan kewajiban hukum bagi yang diperiksa (saksi, ahli, tersangka);
c. berdasarkan fakta hukum;

2) Kegiatan pemeriksaan meliputi:
a. pemeriksaan saksi;
b. pemeriksaan ahli;
c. pemeriksaan tersangka; 
d. pemeriksaan dan penelitian dokumen dan surat - surat;

e. pemeriksaan terhadap alat bukti digital, dsb;

3) Sebelum melakukan pemeriksaan penyidik membuat rencana pemeriksaan;

4) Pemeriksaan terhadap ahli diperlukan dalam kasus tertentu;

5) Untuk menghindari penyimpangan dalam pemeriksaan, wajib dilakukan pengawasan oleh pimpinan;

6) Standar Operasional Prosedur Pelaksanaan Pemeriksaan saksi, Pemeriksaan ahli, Pemeriksaan tersangka, Pemeriksaan dan penelitian dokumen dan surat - surat, Pemeriksaan alat bukti digital tercantum dalam lampiran yang merupakan bagian tidak terpisahkan.

Menurut Pasal 7 Perkaba SOP Pelaksanaan Penyidikan Tahun 2012 tersebutlah kinerja seorang penyidik Kepolisian diatur secara rigid dan detail, sehingga seorang Polisi dalam melaksanakan tugasnya sebagai aparat penegak hukum (Law Enforcement) dituntut harus senantiasa bersikap lebih etis, humanis dan lebih memegang etika profesi Kepolisian serta lebih mengedepankan hak dan kewajiban bagi pencari keadilan dalam melaksanakan tugasnya sebagai fungsi dari Sub Sistem Penyidikan dalam Sistem Peradilan Pidana (Criminal Justice System).

Peradilan pidana dapat diartikan sebagai suatu proses yang bekerja dalam penegakan hukum, kegiatan peradilan meliputi Kepolisian sebagai lembaga penyidikan, Kejaksaan sebagai lembaga penuntutan, Pengadilan sebagai lembaga yang mengadil dan lembaga Pemasyarakat berfungsi untuk memasyarakatkan kembali para si terhukum atau terpidana. Dari Lembaga Peradilan tersebutlah dituntut harus bekerja secara bersama-sama, terpadu didalam usaha untuk menanggulangi kejahatan yang terjadi dalam satu ruang lingkup sistem yang dinamakan Sistem Peradilan Pidana atau dalam bahasa Inggris disebut sebagai Criminal Justice System. Kewenangan masing-masing sub sistem peradilan sebagai lembaga penegak hukum pidana material tersebut bekerja berlandaskan atas substansi hukum pidana formil, yakni Kitab UndangUndang Hukum Pidana (KUHAP). Dalam rangka sistem peradilan pidana tugas polisi terutama sebagai petugas penyidik tercantum dalam ketentuan kitab undang-undang hukum acara pidana. Sebagai petugas penyidik, Polisi bertugas 
untuk menanggulangi pelanggaran ketentuan peraturan pidana, baik yang tercantum didalam maupun diluar ketentuan KUHP. Inilah antara lain tugas Polisi sebagai alat negara penegak hukum. Menurut Barda Nawawi Arief, ${ }^{7}$ sistem peradilan (atau sistem penegakan hukum untuk selanjutnya disingkat $\mathrm{SPH})$ dilihat secara integral, merupakan satu kesatuan sebagai sub-sistem (komponen) yang terdiri dali komponen "substansi hukum" (Legal Substance)," struktur hukum (Legal Structure), dan "budaya hukum” (Legal Culture). Sebagai suatu sistem penegakan hukum, proses peradilan/penegakan hukum terkait erat dengan ketiga komponen itu, yaitu norma hukum/ peraturan perundang-undangan (komponen substantif/ normatif), lembaga/ struktur/ aparat penegak hukum (komponen sktrukural/ institusional beserta mekanisme prosedural/ administrasinya), dan nilai-nilai "budaya hukum" (Legal Culture) dalam konteks penegakan hukum, tentunya lebih terfokus pada nilai-nilai filosofis hukum, nilai-nilai hukum yang hidup dalam masyarakat dan kesadaran/ sikap perilaku hukum/ perilaku sosialnya, dan pendidikan/ ilmu hukum.

\section{Pelaksanaan diskresi kepolisian pada tahap penyidikan}

Penyidik setelah menerima hasil, Menurut pasal 7 ayat (1) KUHAP, penyidik berwenang untuk melakukan penyidikan namun juga berwenang untuk menghentikan penyidikan dan atau mengadakan tindakan lain menurut hukum bertanggung jawab. Letak diskresi dalam kaitan tugas kepolisian preventif dan represif, menurut M. Faal yaitu ada pada tugas kepolisian represif karena pada saat polisi melakukan tindakan represif itulah timbul kebijaksanaan diskresi. Kebijakan diskresi ini muncul sehubungan dengan adanya pelanggaran dan dalam hal ini polisi akan dihadapkan pada dua hal, yaitu apakah akan memproses sesuai dengan tugas sebagai penegak hukum atau tidak melakukan tindakan alias mengenyampingkan perkara dalam arti mengambil tindakan diskresi kepolisian. Artinya tidak melakukan tugas kewajibannya selaku penegak hukum pidana berdasarkan alasan-alasan yang dapat dipertanggungjawabkan. Mengingat akan hal tersebut menurut M. Faal disebutkan bahwa tindakan kepolisian yang berupa

\footnotetext{
${ }^{7}$ Barda Nawawi Arief, 2010, Masalah Penegakan Hukum dan Kebijakan Hukum Pidana dalam Penanggulangan Kejahatan. Kencana, Jakarta, hlm. 31.
} 
menindak (represif) yang kemudian dilanjutkan dengan tindakan 4 diskresi ini, disebut dengan tindakan diskresi kepolisian aktif, sedangkan keputusan kepolisian yang berupa sikap kepolisian yang umunya mentolerir (mendiamkan) suatu tindak pidana atau pelanggaran hukum disebut diskresi pasif. ${ }^{8}$

Polisi dalam pelaksanaan tugas penyelidikan/penyidikan, menurut Soerjono Soekanto dipengaruhi oleh beberapa faktor seperti ${ }^{9}$ :

a. Faktor undang-undang, yaitu hukum tertulis maupun yang tidak tertulis. Seperti dalam pasal 16 ayat (1) huruf 1 dan pasal 18 ayat (1) Undang-Undang Nomor 2 Tahun 2002 tentang Kepolisian Negara Republik Indonesia, yang menyatakan bahwa polisi dapat mengadakan tindakan lain menurut pertimbangannya sendiri.

b. Faktor penegak hukum, dalam hal ini tingkat intelegensi dan profesionalisme aparat Kepolisian yang sangat menentukan pengambilan tindakan diskresi kepolisian tersebut.

c. Faktor masyarakat, yaitu dimana masyarakat baik korban maupun pelaku atau tersangka tindak pidana yang menginginkan penyelesaian yang cepat tanpa melalui pengadilan memberikan akses bagi polisi untuk mengambil tindakan diskresi dalam penghentian penyidikan.

d. Faktor sarana prasarana, hal ini berkaitan dengan fasilitas yang diberikan kepada aparat penegak kepolisian seperti sarana mobilitas, komunikasi, serta anggaran untuk menyelesaikan perkara pidana. Misalnya penghentian penyidikan perkaraperkara yang ringan guna menghemat anggaran yang nantinya bisa digunakan untuk menyelesaikan perkara yang lebih berat.

e. Faktor budaya hukum yakni taktik dan teknik penyidikan tindak pidana sudah merupakan budaya yang berlaku dalam setiap penyidikan baik yang bersifat positif maupun yang bersifat negatif seperti tindakan kekerasan yang dilakukan dalam pemeriksaan.

\section{Efektifitas Pelaksanaan diskresi kepolisian pada tahap penyidikan}

\footnotetext{
${ }^{8}$ M. Faal, 1997, Penyaringan Perkara Pidana Oleh Polisi (Diskresi Kepolisian), Pradnya Paramita, Jakarta, hlm. 69.

${ }^{9}$ Soerjono Soekanto, 2011, Faktor-Faktor yang Mempengaruhi Penegakan Hukum, Jakarta, hlm. 8 .
} 
Diskresi dalam Black Law Dictionary berasal dari bahasa Belanda "Discretionair" yang berarti kebijaksanaan dalam halnya memutuskan sesuatu tindakan tidak berdasarkan ketentuan-katentuan peraturan, Undang-undang atau hukum yang berlaku tetapi atas dasar kebijaksanaan, pertimbangan atau keadilan. ${ }^{10}$ Diskresi sering dirumuskan sebagai "Freis Ermessen" Menurut kamus hukum yang disusun oleh Simorangkir JCT, diskresi diartikan sebagai "kebebasan mengambil keputusan dalam setiap situasi yang dihadapi menurut pendapatnya sendiri". ${ }^{11}$

Didalam Pasal 18 UU Polri Nomor 2 Tahun 2002, menjelaskan bahwa :

1. Untuk kepentingan umum pejabat Kepolisian Negara Republik Indonesia dalam melaksanakan tugas dan wewenangnya dapat bertindak menurut penilaiannya sendiri.

2. Pelaksanaan ketentuan sebagimana dimaksud dalam ayat (1) hanya dapat dilakukan dalam keadaan yang sangat perlu dengan memperhatikan peraturan perundang-undangan, serta Kode Etik Profesi Kepolisian Negara Republik Indonesia.

Kalimat dalam Pasal 18 tersebut yang berbunyi "bertindak menurut penilaian sendiri" merujuk kepada konsep diskresi atau "Freies Ermessen". Dalam bahasa Inggris, diskresi (Discretion) mengandung arti, "the quality of being discreet, or careful about what one does and says", dari kalimat tersebut mempunyai makna yakni kualitas yang bijaksana, atau berhati-hati tentang apa yang dilakukan dan dikatakan. Jadi, inti dari makna kata diskresi yang telah dijelaskan diatas yakni harus dilakukan dengan penuh kehati-hatian.

Dalam bahasa UU Polri Nomor 2 Tahun 2002 tersebut diskresi dirumuskan sebagai "dalam keadaan yang sangat perlu”. Penjelasan resmi dari UU tersebut berbunyi, "yang dimaksud dengan 'bertindak menurut penilaiannya sendiri adalah suatu tindakan yang dapat dilakukan oleh anggota Kepolisian Negara Republik Indonesia yang dalam bertindak harus mempertimbangkan

\footnotetext{
${ }^{10}$ Yan Pramadya Puspa, 1977, Kamus Hukum, Aneka, Semarang, hlm. 91.

${ }^{11}$ JCT. Simorangkir, 2002, Kamus Hukum, Aksara Bar, Jakarta, hlm. 38.
} 
manfaat serta resiko dari tindakannya dan betul-betul untuk kepentingan umum". ${ }^{12}$

Diskresi adalah kebebasan untuk memilih berbagai langkah tindakan (Caurses of action or inaction). Diskresi membutuhkan tingkat kecerdasan yang memadai dalam mengambil keputusan. Dalam hal ini sumber daya manusia (SDM) penegak hukum memegang peranan penting dari pada isi dari produknya, atau dalam hal ini adalah Peraturan Perundang-undangan saja (to improve the human resources is more important than it's product), mengingat pentingnya penegak hukum (Kepolisian, Kejaksaan dan Kehakiman ataupun Advokad) harus berani keluar dari alur tradisi penegakan hukum yang hanya didasarkan pada peraturan perundang-undangan semata, sebab hukum bukanlah hanya ruang hampa yang steril dari konsep-konsep non hukum. Ia harus dilihat dari perspektif sosial, perilaku yang senyatanya yang dapat diterima oleh manusia yang ada didalamnya.

Kualitas sumberdaya manusia penegak hukum adalah faktor menentu, jalannya suatu Sistem Peradilan Pidana (Criminal Justice System) oleh karena itu peningkatan profesionalisme, integritas dan disiplin merupakan upaya penting yang harus dilakukan tiada henti. Selain itu perlu setiap penegak hukum bertindak proporsional serta memiliki kemandirian, kearifan dan perilaku hukum yang baik, agar kepastian hukum, keadilan dan kemanfaatan hukum sebagai tata hukum atau nilai dasar dari cita hukum dapat diwujudkan di negeri tercinta ini.

Kewenangan diskresi adalah suatu kekuasaan atau wewenang yang dilakukan berdasarkan hukum atas dasar pertimbangan dan keyakinan dan lebih menekankan pada pertimbangan moral ketimbang pertimbangan hukum. Diskresi itu dilakukan bukan lepas dari ketentuan hukum tetapi diskresi itu tetap dilakukan dalam kerangka hukum. Oleh karena itu praktek Kepolisian demi kepentingan umum dapat dipandang sebagai upaya pengayoman sehingga dapat berlangsung. Secara tegas dijelaskan dalam Penjelasan Undang-Undang No. 2 Tahun 2002 Tentang Kepolisian Negara Republik Indonesia bahwa :

"tindakan pencegahan tetap diutamakan melalui pengembangan asas preventif dan asas kewajiban umum Kepolisian yaitu memelihara keamanan dan

\footnotetext{
${ }^{12}$ Satjipto Rahardjo, 2010, Sosiologi Hukum, Genta Publishing, Yogyakarta, hlm. 103.
} 
ketertiban masyarakat. Dalam hal ini setiap pejabat Kepolisian Negara Republik Indonesia memiliki kewenangan diskresi yaitu kewenangan untuk bertindak demi kepentingan umum berdasarkan penilaian sendiri.

Uundang-undang mengatur, pula pembinaan profesi dan kode etik profesi agar tindakan pejabat Kepolisian Negara Republik Indonesia dapat dipertanggungjawabkan baik secara hukum, moral maupun secara teknik profesi dan terutama hak asasi manusia".

Meskipun Polisi itu bertindak seolah-olah justru tidak berdasarkan hukum positif yang berlaku, namun apabila dikaji lebih justru itu suatu tindakan yang dapat menjunjung tinggi tujuan hukum itu sendiri yaitu perlindungan terhadap setiap warga negara yang berdasarkan atas keadilan, kemaslahatan dan kemanfaatan hukum itu sendiri untuk membahagiakan rakyatnya.

Pemberian diskresi kepada Polisi pada hakekatnya bertentangan dengan Negara yang didasarkan pada hukum (Rechtstaats). Diskresi ini menghilangkan kepastian terhadap apa yang terjadi, tetapi suatu tatanan dalam masyarakat yang sama sekali berlandaskan pada hukum juga merupakan suatu ideal yang tidak akan dicapai. Di sini dikehendaki, bahwa semua hal dan tindakan diatur oleh peraturan yang jelas dan tegas, suatu keadaan yang tidak dapat dicapai.

Berdasarkan pandangan Chamblis dan Saidman, maka dapat diartikan bahwa hukum merupakan suatu bentuk ide-ide yang mengatur secara terperinci dan mendetail dengan memberikan suatu bentuk arah pada kehidupan bersama dan bersifat umum, maka pada saat itu pula kehidupan akan mengalami kemacetan. Sekalipun Polri dalam melakukan diskresi terkesan melawan hukum, namun hal itu merupakan jalan keluar yang memang diberikan oleh hukum kepada Polri guna memberikan efektivitas demi kepentingan umum yang lebih luas.

Dengan dimilikinya kekuasaan diskresi oleh polisi maka polisi mempunyai kewenangan dalam menerobos suatu bentuk kekakuan hukum yang lebih menonjolkan sisi legisme semata, tanpa memperhatikan stelsel-stelsel kemasyarakatan yang hidup dimasyarakat dalam mencapai suatu bentuk kemaslahatan dan keadilan yang nyata. Dari hal tersebut, maka bentuk diskresi yang diberikan kepada Polisi merupakan suatu bentuk terobosan terhadap 
penegakan hukum secara nyata dengan tetap memberikan suatu bentuk keadilan yang nyata dengan memperhatikan sisi resiko dan kemanfaatan dari suatu tindakan yang dilaksanakan.

Meskipun demikian teorinya, dalam praktiknya masih banyak ditemukan peristiwa dimana penggunaan "diskresi" dilakukan tidak sesuai dengan standar operasional prosedur. Hal ini tentu merugikan masyarakat karena aspek keadilan di dalam penegakan hukum tidak terpenuhi.

\section{KESIMPULAN}

Penggunaan diskresi kepolisian dalam penghentian penyidikan, tampak adanya wewenang dalam hal atau keadaan tertentu untuk mengambil keputusan apakah akan dilakukan tindakan atau tidak apabila terjadi suatu tindak pidana. Faktor-faktor yang mempengaruhi diskresi kepolisian dalam penghentian penyidikan antara lain faktor undang-undang; faktor penegak hukum; faktor masyarakat; faktor sarana prasarana; dan faktor budaya hukum; dan Pelaksanaan diskresi secara efektif harus dilakukan dengan penuh kehati-hatian dengan meningkatkan kualitas sumberdaya manusia dibidang penegakan hukum serta kekuasaan atau wewenang yang dilakukan berdasarkan hukum atas dasar pertimbangan dan keyakinan dan lebih menekankan pada pertimbangan moral ketimbang pertimbangan hukum serta memberikan keadilan yang nyata dengan memperhatikan sisi resiko dan kemanfaatan dari suatu tindakan yang dilaksanakan.

\section{E. SARAN}

Perlu diatur secara tegas dalam peraturan perundang-undangan; dan Penggunaan diskresi kepolisian harus memperhatikan kemaslahatan masyarakat umum agar dalam pelaksanaannya tidak bertentangan atau melawan hukum.

\section{DAFTAR PUSTAKA}

Anton Tabah. 2002. Membangun Polri yang Kuat (Belajar Macam-Macam Asia), Mitra Hardhasuma, Jakarta.

Faal. M. 1997. Penyaringan Perkara Pidana Oleh Polisi (Diskresi Kepolisian), Pradnya Paramita, Jakarta Moylan. 1953. Pengertian Kepolisian, Gramedia Widia Sarana Indonesia, Jakarta.

Nawawi Arief, Barda. 2010. Masalah Penegakan Hukum dan Kebijakan Hukum Pidana dalam Penanggulangan Kejahatan. Kencana, Jakarta.

Pramadya Puspa, Yan. 1977. Kamus Hukum, Aneka, Semarang. 
Rahardjo, Satjipto. 2010. Sosiologi Hukum, Genta Publishing, Yogyakarta.

Simorangkir, JCT. 2002. Kamus Hukum, Aksara Baru, Jakarta.

Soekanto, Soerjono. 2011. Faktor-Faktor yang Mempengaruhi Penegakan Hukum, Jakarta.

Republik Indonesia, Undang-Undang Dasar 1945.

-------------, Undang-Undang Nomor 8 tahun 1981 tentang Hukum Acara Pidana.

------------------, Undang-Undang Nomor 2 Tahun 2002 tentang Kepolisian Negara Republik Indonesia.

-------------------,Peraturan Pemerintah Nomor 58 Tahun 2010 tentang pelaksanaan Kitab Undang-undang Hukum Acara Pidana. 